\title{
EFFECTS OF DIFFERENT LEVELS OF DIETARY BIOTIN ON THE PERFORMANCE, APPARENT DIGESTIBILITY AND CARCASS CHARACTERISTICS OF BROILERS
}

\author{
Nareen Abdulaziz SHekhu, Shawkat AbdulRaZaq M'SadeQ, \\ SLEMAN SAID MOHAMMED BESKI and KURDMAN SULAIMAN \\ Dept. of Animal Production, College of Agricultural Engineering Sciences , University of Duhok, \\ Kurdistan region -Iraq
}

(Accepted for Publication: October 21, 2019)

\begin{abstract}
This experiment was conducted to investigate the efficacy of different levels of biotin on broilers' performances, protein and fat apparent digestibility and carcass characteristics. The study was conducted at University of Duhok, College of agriculture, Animal House Complex. A total of 160-day-old Ross 308 randomly assigned to 4 treatments with four replicate pens per treatment and 10 birds each pen. Treatments were control diet without additive and three levels of biotins which are biotin 1 , biotin 2 and biotin 3 at concentrations 1000,1500 and $2000 \mathrm{mg} / 10 \mathrm{~L}$ of drinking water respectively during the whole rising period. The results showed that different levels of biotin increased body weight gain (WG) and biotin2 and biotin 3 improved Feed conversion ratio (FCR) compared to control group at day 35. Adding different levels of biotin in drinking water had significantly higher protein digestibility over non-treated group. In conclusion, adding biotin to broiler water had positive effect on WG, FCR and protein digestibility.
\end{abstract}

KEY WORDS: Meat chickens, apparent digestibility, growth performance, carcass characteristics. https://doi.org/10.26682/cajuod.2020.22.2.14

\section{INTRODUCTION}

B iotin is an important coenzyme for all organisms. Active form of biotin is linked to enzymes of metabolic importance for instance, biotin decarboxylase and biotin carboxylase. Also, biotin is a key-enzyme in important processes such as protein and fatty acids synthesis, gluconeogenesis and controlling scleroprotein production. Biotin contributes into important processes such as skin regeneration, reproduction, growth and bone development, increasing feed conversion in animals Mcmahon (2002). Biotin coenzyme which provided in birds cannot be synthesize, under physiological conditions, by gut flora microbial synthesis Payne et al., (1974). It is essential to avoid vitamin deficiency such as deformed bones and perosis of chickens. In synthetic form, Biotin (Vitamin-H) is essential in several enzymes particularly for decarboxylation of amino acids and trans-amination Memon (2007). Shortage of biotin in broilers, cause skin diseases like the softening hard tissue in claws and beaks and dermatitis with subsequent loss of plumage or bone deformities (El-Wahab, et al.,2013; Harms and Simpson, 1977; Harms and Simpson,1975; Oloyo and Ogunmodede, 1992; Stock and Latshaw, 1981; Summers, et al., 1978). In poultry industry the particular damages are symptoms connected to feed conversion ration reduction and low growth (Ferguson et al., 1978), which decreased productivity and reproductive performance. The objectives of this study are to evaluate the effects of different doses of biotin supplementation in broiler chickens drinking water on performance, protein and fat digestibility and carcass characteristics.

\section{MATERIAL AND METHODS}

The experiment was approved by the scientific Committee of the Animal Production Department of the University of Duhok. The biotin product was purchased commercially in Duhok Provence. 


\section{Animal Husbandry}

A total of 160 d-old male Ross 308 chicks were placed in 16 floor pens in an aviary of the Animal House Complex, College of agriculture University of Duhok. All the birds were vaccinated against Newcastle disease and infectious bronchitis. These birds were randomly assigned to 4 treatments with four replicate pens per treatment and 10 birds each pen. Pens (wire mesh partitioned at $100 \times 100 \mathrm{~cm}$ ) were assigned. The temperature and lighting program were adjusted according to Ross 308 guideline (Aviagen 201). Each pen was equipped with a separate tube feeder and nipple drinkers with water and feed provided ad libitum. During the trial period, starter diets were fed during d 0-10, grower diets between d 10-24, and finisher diets between $d$ 24-35. The chemical composition of the experimental diets is presented in Table 1 . The primary determinants of performance, i.e., body weight gain (WG), feed intake (FI), feed conversion ratio (FCR) and water intake (WI) were measured at $\mathrm{d} 10,24$ and 35.

\section{Dietary Treatment}

Commercial diet was purchased for the experiment. The dietary treatments were as follows: 1) control diet without additive; 2) Biotin 1; birds fed control diet and 1000mg biotin / $10 \mathrm{~L}$ added to drinking water in starter, grower and finisher phases 3) Biotin 2; birds fed control diet and $1500 \mathrm{mg}$ biotin / $10 \mathrm{~L}$ added to drinking water in starter, grower and finisher phases 4) Biotin 3; birds fed control diet and $2000 \mathrm{mg}$ biotin / $10 \mathrm{~L}$ added to drinking water in starter, grower and finisher phases .

\section{Sample collection}

On day 35, two birds from each pen were randomly selected, weighed and killed. Organs weight including liver, heart, spleen, gizzard, bursa, and pancreas and carcass characteristics were taken. Foot pad lesion scores were taken according to the scoring method of (Allain, et al., 2009), where a score of 0 (minimum score; no lesion) to 9 (maximum score; severe foot pad dermatitis and extensive tissue necrosis).

For apparent digestibility, 3 birds from each pen were transferred to the metabolizable energy cages at day 35 to measure the nutrients digestibility. Ten fresh droppings were collected from each cage, and dried for $24 \mathrm{~h}$ at $105{ }^{\circ} \mathrm{C}$. The apparent digestibility was calculated using the formula (nutrient intake - nutrient excrete)/nutrient intake, and expressed as \% wet weight.

\section{Statistical Analysis.}

The SAS statistical package (2013) was used to determine statistical significance. Means were separated using Duncan's multiple range test

\section{Broiler performance}

\section{RESULTS}

Performance results are presented in Table (2). Performance results from day 0 to day 35 showed that the birds with different levels of biotin had higher WG compared to control group $(\mathrm{P}=0.04)$. Inclusion of biotin 2 and biotin 3 significantly improved the FCR over control. The supplementation of biotin did not affect FI at day 10, 24 and 35 and no significant differences were observed for WG and FCR at day 10 and 24.

For water consumption, no significant differences were detected between treatments at day 10 and 35, whereas the water intake in birds fed control diet was higher than those fed different levels of biotin at Day 24.

\section{Carcass characteristics and organ weights}

Table 3 and 4 show measurements of carcass characteristics and relative lymphoid organ weights at day 35 . Dietary treatments had no effect on carcass characteristics including dressing $\%$, breast $\%$, thigh $\%$, and drumstick $\%$ $(\mathrm{P}>0.05)$ (table 2). As shown in table 3, no differences detected $(\mathrm{P}>0.05)$ among the treatment groups for relative heart, spleen, gizzard, pancreas and bursa of Fabricius weight. There were no significant differences of foot pad lesion scores between treatments at day 35 .

\section{Protein and fat apparent digestibility}

Results of protein and fat apparent digestibility of protein are shown in figure 1 . Apparent digestibly of birds supplemented with different levels of biotin had significantly higher protein digestibility over birds fed control diet. Although no significant effect of biotin was observed, birds that have drunk water supplemented with different levels of biotin have had numerically improved fat digestibility compared with to birds fed control diet. 
Journal of University of Duhok.,Vol. 22, No.2(Agri. and Vet. Sciences),Pp124-130, 2019(Special Issue) The $3^{\text {rd }}$ International Agricultural Conference, $2^{\text {nd }}-3^{\text {rd }}$ October 2019, Duhok

Table (1): Proximate analysis of the experimental diets

\begin{tabular}{lccc}
\hline Nutrients \% & Starter & Grower & Finisher \\
\hline Crude protein & 24.8 & 22.50 & 19.25 \\
\hline ME, kcal/kg & 3,025 & 3,100 & 3,150 \\
\hline C:P ratio (Cal.) & 121.98 & 137.78 & 163.64 \\
\hline Moisture (Det.) & 7.61 & 7.62 & 7.46 \\
\hline Dry matter (Det.) & 92.39 & 92.38 & 92.54 \\
\hline Ether extract (Det.) & 4.50 & 4.80 & 7.10 \\
\hline Ash (Det.) & 6.90 & 5.96 & 5.40 \\
\hline
\end{tabular}

Table (2): Effect of biotin on growth performance of broiler chickens (1-35) days of age.

\begin{tabular}{|c|c|c|c|c|c|c|}
\hline period & Control & Biotin 1 & Biotin2 & Biotin3 & $P$ value & Pooled SEM \\
\hline \multicolumn{7}{|c|}{ Body weight gain (g/bird) } \\
\hline $1-10 d$ & 242 & 257 & 259 & 256 & 0.09 & 3.06 \\
\hline $1-24 d$ & 1052 & 1071 & 1085 & 1083 & 0.64 & 9.38 \\
\hline $1-35 d$ & $1872^{b}$ & $1973^{a}$ & $1973^{a}$ & $2012^{\mathrm{a}}$ & 0.04 & 19.27 \\
\hline \multicolumn{7}{|c|}{ Feed intake (g/bird) } \\
\hline $1-10 d$ & 275 & 283 & 285 & 279 & 0.52 & 2.53 \\
\hline $1-24 d$ & 1386 & 1392 & 1419 & 1409 & 0.78 & 11.71 \\
\hline $1-35 d$ & 2718 & 2825 & 2799 & 2838 & 0.40 & 26.41 \\
\hline \multicolumn{7}{|c|}{ Feed conversion ratio (FCR) } \\
\hline $1-10 d$ & 1.14 & 1.10 & 1.10 & 1.14 & 0.25 & 0.01 \\
\hline $1-24 d$ & 1.32 & 1.30 & 1.31 & 1.31 & 0.77 & 0.01 \\
\hline $1-35 d$ & $1.48^{\mathrm{a}}$ & $1.43^{\mathrm{ab}}$ & $1.42^{\mathrm{b}}$ & $1.41^{b}$ & 0.04 & 0.01 \\
\hline \multicolumn{7}{|c|}{ Water intake (ml/bird) } \\
\hline $1-10 d$ & 808 & 754 & 756 & 694 & 0.09 & 16.24 \\
\hline $1-24 d$ & $3637^{a}$ & $3312^{b}$ & $3373^{b}$ & $3377^{b}$ & 0.01 & 41.45 \\
\hline $1-35 d$ & 6981 & 6774 & 6773 & 6660 & 0.46 & 68.75 \\
\hline
\end{tabular}

a, b -Means within the same row with different superscripts differ significantly $(\mathrm{p}<0.05)$.

Treatments: control $=$ no additive, Biotin $1=1000 \mathrm{mg}$ biotin $/ 10 \mathrm{~L}$ of drinking water, Biotin $2=1500 \mathrm{mg}$ biotin/

$10 \mathrm{~L}$ of drinking water, Biotin $3=2000 \mathrm{mg}$ biotin $/ 10 \mathrm{~L}$ of drinking water. 
Table (3): Effect of biotin on carcass characteristics of broilers at day 35 of age.

\begin{tabular}{lcccc}
\hline Treatment means & Dressing $\%$ & Breast $\%$ & Thigh $\%$ & Drumstick \% \\
\hline Control & 72.71 & 36.10 & 15.12 & 12.76 \\
\hline Biotin 1 & 74.96 & 36.25 & 14.79 & 12.77 \\
\hline Biotin 2 & 73.40 & 38.00 & 15.34 & 13.53 \\
\hline Biotin 3 & 73.55 & 35.91 & 0.82 & 0.63 \\
\hline P value & 0.13 & 0.59 & 0.22 & 0.17 \\
\hline Pooled SEM & 0.35 & 0.58 & & \\
\hline
\end{tabular}

Treatments: control $=$ no additive, Biotin $1=1000 \mathrm{mg}$ biotin $/ 10 \mathrm{~L}$ of water, Biotin $2=1500 \mathrm{mg}$ biotin $/ 10 \mathrm{~L}$ of water, Biotin $3=2000 \mathrm{mg}$ biotin/ $10 \mathrm{~L}$ of water.

Table (4): Effect of biotin on the relative weight of organs to live body weight and foot pad lesion score of birds at 35 days of age.

\begin{tabular}{lcccccc}
\hline & Control & Biotin 1 & Biotin2 & Biotin3 & P value & Pooled SEM \\
\hline Liver \% & 2.61 & 2.49 & 2.61 & 2.64 & 0.71 & 0.05 \\
\hline Heart \% & 0.62 & 0.63 & 0.57 & 0.69 & 0.27 & 0.02 \\
\hline Gizzard \% & 2.07 & 2.18 & 2.68 & 2.70 & 0.21 & 0.13 \\
\hline Bursa \% & 0.17 & 0.17 & 0.11 & 0.11 & 0.26 & 0.01 \\
\hline Spleen \% & 0.17 & 0.13 & 0.24 & 0.14 & 0.54 & 0.03 \\
\hline $\begin{array}{l}\text { Pancreas \% } \\
\text { Foot pad lesion }\end{array}$ & 0.21 & 0.20 & 0.17 & 0.23 & 0.26 & 0.01 \\
\hline score & 1.75 & 1.00 & 1.53 & 0.94 & 0.59 & 0.24 \\
\hline
\end{tabular}

Treatments: control $=$ no additive, Biotin $1=1000 \mathrm{mg}$ biotin $/ 10 \mathrm{~L}$ of water, Biotin $2=1500 \mathrm{mg}$ biotin/ $10 \mathrm{~L}$ of water, Biotin 3=2000 mg biotin/ $10 \mathrm{~L}$ of water. 


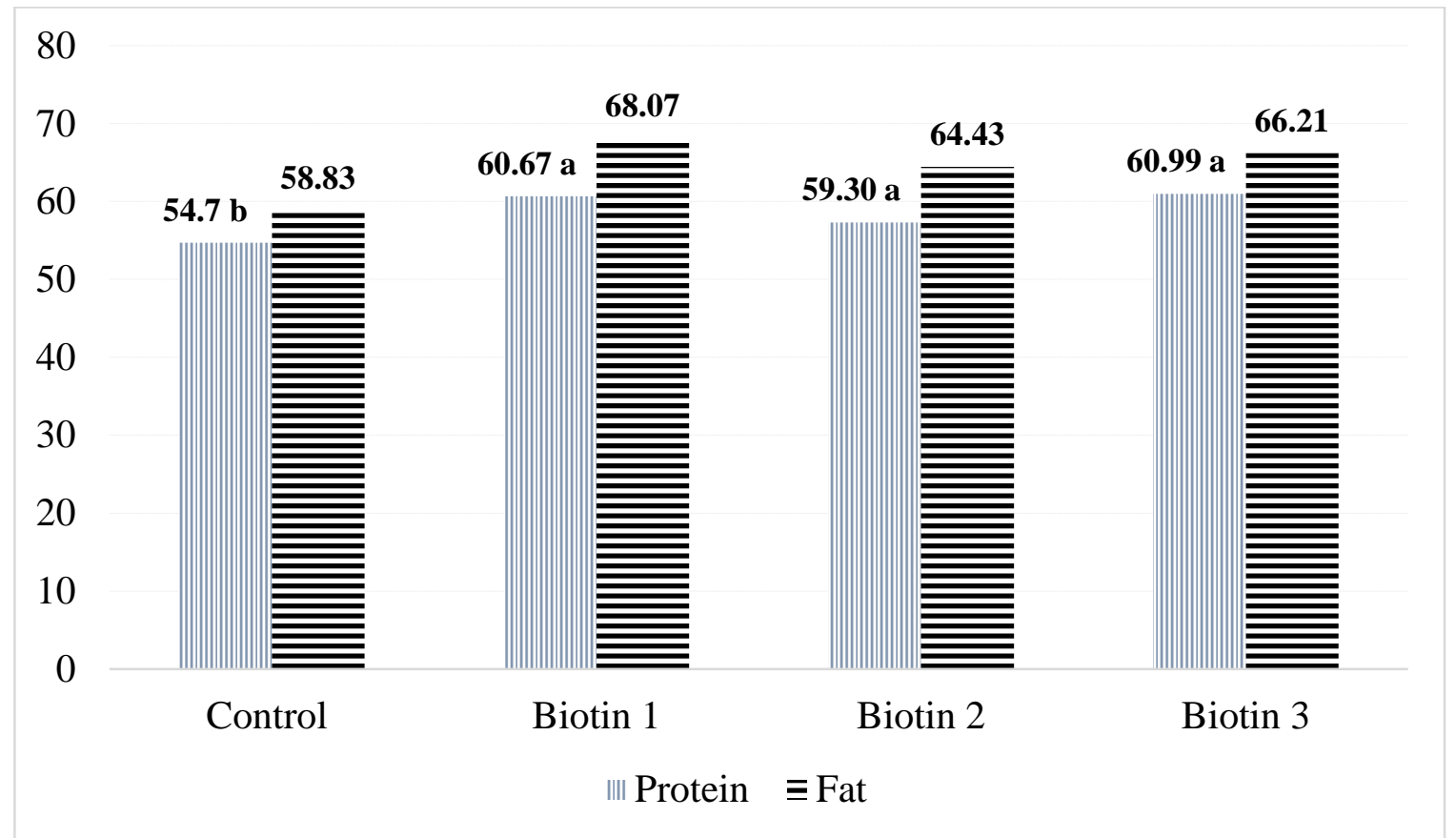

Fig (1): Effect of biotin on the apparent digestibility of protein and fat of birds at 35 days of age. Treatments: control= no additive, Biotin 1= 1000mg biotin $/ 10 \mathrm{~L}$ of drinking water, Biotin $2=1500 \mathrm{mg}$ biotin/ $10 \mathrm{~L}$ of drinking water, Biotin $3=2000 \mathrm{mg}$ biotin/ $10 \mathrm{~L}$ of drinking water.

a,b- different letters in the same graph indicate significant differences between treatment means, $\mathrm{p}<0.05$.

\section{DISCUSSION}

Improved broiler performance to be achieved in modern poultry production, vitamin supplementation may increase the health of birds and also their production.

The present study showed that different levels of biotin improved body weight gain and FCR. This was inconsistent with finding of Memon, (2007) when $300 \mathrm{mg} / \mathrm{Kg}$ biotin maximum weight gain and decreased FCR in compare to other dietary groups. (Quarantelli, et al., 2007) reported that Biotin at dosages of $200,300,400 \mathrm{mg} / \mathrm{Kg}$ improved body weight and FCR in the second and third period of growth at day 41 and 61. Similarly, (Abd El-Wahab, et al., 2013) found that birds fed high levels of biotin combined with Zn-Met numerically increased live body weight $(2219 \mathrm{~g})$ compared with the other treated groups. Contrary to these findings, (Harms and Simpson 1977) stated that the biotin supplementation had no effect on body weight of turkey poults. The improvement of performance by dietary biotin may be due to that biotin improve protein and fat digestibility. As present study results indicated that addition of biotin in birds' drinking water had improved protein and fat digestibility, biotin is an essential coenzyme in fat, protein and carbohydrate metabolism. It is involved in conversion of protein to carbohydrate and conversely. Biotin also involves in conversion of carbohydrate and protein to fat. When dietary carbohydrate is low, biotin plays a vital role in keeping normal blood glucose levels from metabolism of protein and fat Quarantelli, et al., (2007). There is some evidence that biotin deficiency causes growth disorder as it required in several enzymes particularly for decarboxylation of amino acids and trans-amination (Goldberg, et al,. 1995) which have positive effect on bird's health and performance.

The results of this study indicated that dietary supplementation of biotin had no significant effect on carcass characteristic, organs relative weight and foot pad lesion score at day 35. This was the case in (Sun et al,. 2017) studies when dietary biotin had no significant improvement on foot pad lesion score. However, (Abd El-Wahab, et al., 2013) found that feeding different levels of biotin resulted in significantly decreased food pad lesion scores in comparison with groups that fed control diet. Biotin supplementation did not affect the food pad lesion score in present study may be due to that the litter quality throughout this experiment was good and biotin may have effect during poor litter quality as stated in previous studies. For the carcass characteristics and organs relative weight, biotin as feed additive in broiler ration at different levels 
significantly increased carcass weight, heart weight, gizzard weight, liver weight when compared to birds fed control diet ( Buda, 2000, Memon, 2007 and Santin et al.,2000). This was in contrast to the present study data when biotin had not affected carcass characteristics and relative organs weight.

\section{CONCLUSION}

The data of current study confirm that supplemental biotin has a favorable effect on growth performance. The results demonstrated that adding biotin to broiler water had improved body weight gain and feed conversion ratio. However, biotin had no effect on carcass characteristics and relative organs weight.

\section{REFERENCES}

Allain, V., Mirabito, L., Arnould, C., Colas, M., Bouquin, S. L., Lupo, C., \& Michel, V. (2009). Skin lesions in broiler chickens measured at the slaughterhouse: relationships between lesions and between their prevalence and rearing factors. British Poultry Science, 50(4), 407-417.

Buda, S. (2000). Effects of biotin on the skin of turkey foot pads. World Poultry, 16(12):47-48

El-Wahab, A. A., Radko, D., \& Kamphues, J. (2013).

High dietary levels of biotin and zinc to improve health of foot pads in broilers exposed experimentally to litter with critical moisture content. Poultry Science, 92(7):1774-1782.

Ferguson, A. E., Leeson, S., Julian, R. J., \& Summers, J. D. (1978). Leg Bone Abnormalities and Histopathology of Caged and Floor Reared Broilers Fed Diets Devoid of Selected Vitamins and Minerals. Poultry Science, 57(6), 1559-1562.

Goldberg, J., Huang, H.-B., Kwon, Y.-G., Greengard, P., Nairn, A. C., \& Kuriyan, J. (1995). Threedimensional structure of the catalytic subunit of protein serine/threonine phosphatase1. Nature, 376(6543), 745-753.

Harms, R. H., \& Simpson, C. F. (1975). Biotin Deficiency as a possible Cause of Swelling and Ulceration of Foot Pads. Poultry Science, 54(5), 1711-1713.
Harms, R. H., \& Simpson, C. F. (1977). Influence of Wet Litter and Supplemental Biotin on Foot Pad Dermatitis in Turkey Poults. Poultry Science, 56(6), 2009-2012.

Mcmahon, R. J. (2002). Biotin Inmetabolism Andmolecularbiology. Annual Review of Nutrition, 22(1), 221-239.

Memon, M. (2007). Effect of biotin as a feed additive on the growth of broiler. International Journal of Innovative Agriculture \& Biology Research, 4(2), 17-25.

Oloyo, R. A., \& Ogunmodede, B. K. (1992). Preliminary Investigation on the Effect of Dietary Supplemental Biotin and Palm Kernel Oil on Blood, Liver and Kidney Lipids in Chicks. Archiv Für Tierernaehrung, 42(3-4), 263-272.

Payne, C. G., Gilchrist, P., Pearson, J. A., \& Hemsley, L. A. (1974). Involvement of biotin in the fatty liver and kidney syndrome of broilers. British Poultry Science, 15(5), 489498.

Quarantelli, A., Cacchioli, A., Romanelli, S., Righi, F., Alpigiani, I., \& Gabbi, C. (2007). Effects of different levels of dietary biotin on the performance and bone structure of broilers. Italian Journal of Animal Science, 6(1), 5-7.

Santin, E., A, Maiorka., G, Segatto., and I, Zanella. (2000). Influence of different levels of vitamins A, B6, folic acid and biotin, in broilers diets on broiler performance. Ars Veterinaria, 16(1), 52-57.

Stock, R. H., \& Latshaw, J. D. (1981). The Effects of Manganese, Biotin, and Choline on Hexosamine and Hydroxyproline Content as Related to Leg Weakness. Poultry Science, 60(5), 1012-1016.

Summers, J. D., Leeson, S., \& Ferguson, A. E. (1978). Performance and Leg Conditions of Caged and Floor Reared Broilers Fed Diets Deficient in Selected Vitamins and Minerals. Poultry Science, 57(2), 506-512.

Sun, Z. W., Fan, Q. H., Wang, X. X., Guo, Y. M., Wang, H. J., \& Dong, X. (2017). High dietary biotin levels affect the footpad and hock health of broiler chickens reared at different stocking densities and litter conditions. Journal of Animal Physiology and Animal Nutrition, 101(3), 521-530. 


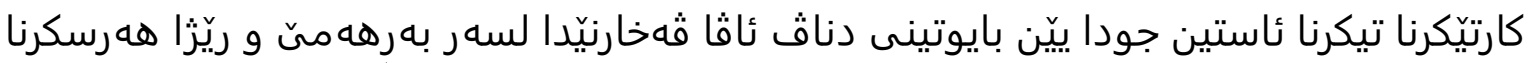

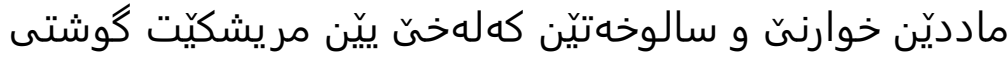

يوخته

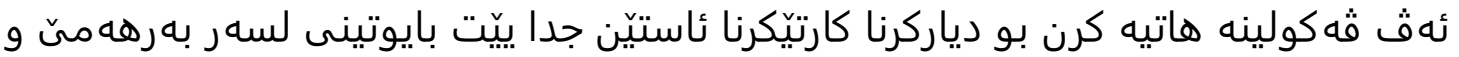

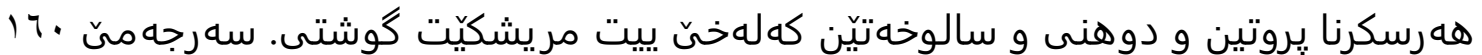

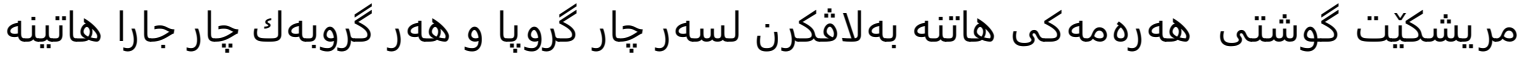

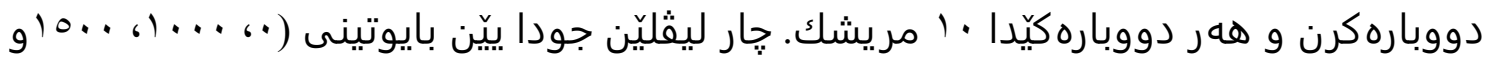

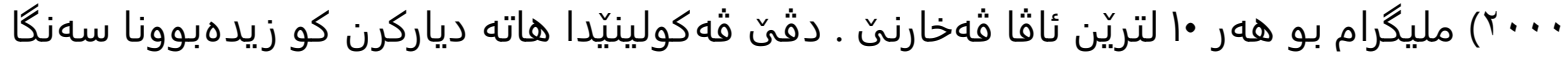

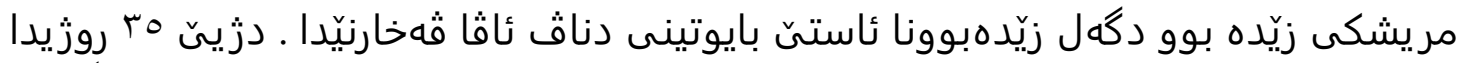

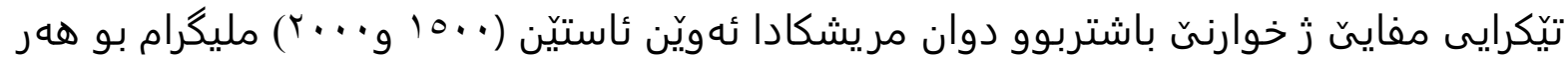

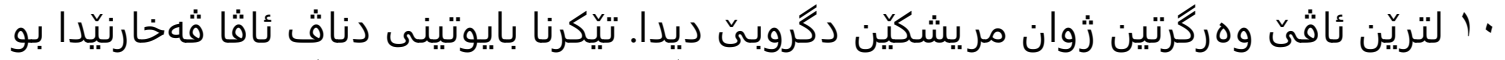

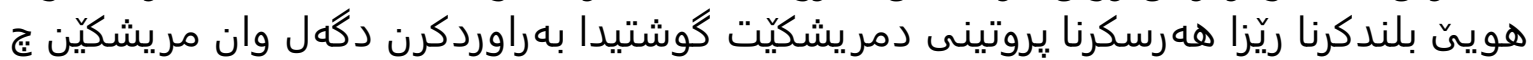

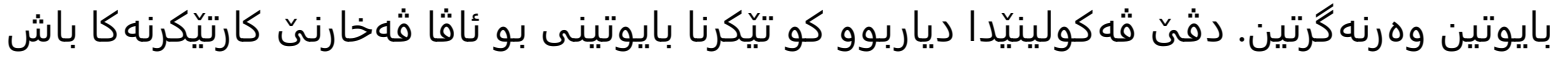

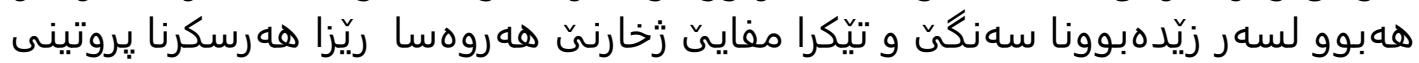
دمريشكيّن كوشتيدا.

تاثير اضافة مستويات مختلفة من البيوتين الى مياه الشرب على الاداء الانتاجي و معمل هضم العناصر الغذائية و صفات الذبيحة لدجاج فروج اللحم

المستخلص هذه الدراسة لمعرفة مدى تاثير اضافة مستويات مختلفة من البيوتين على الاداء

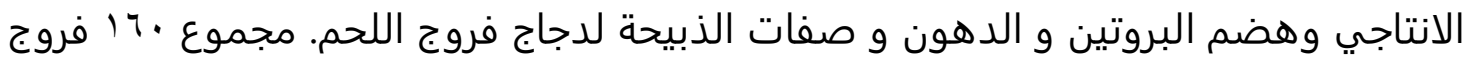

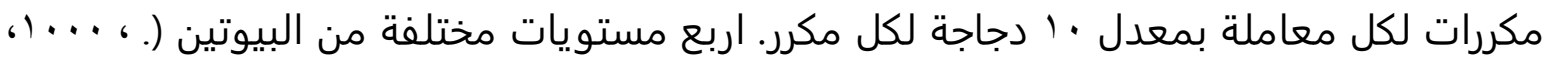

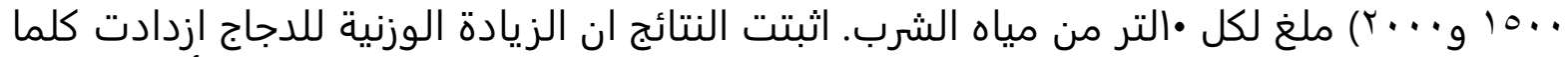

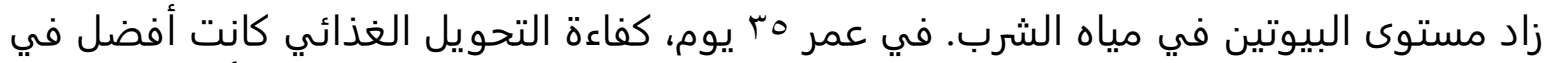

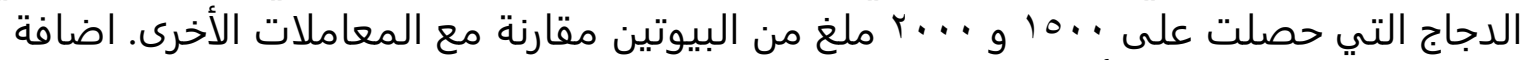

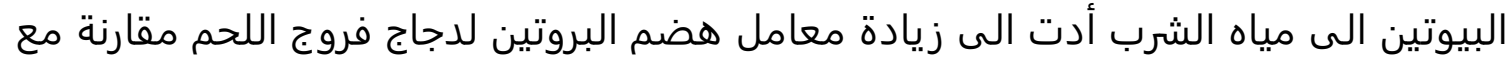

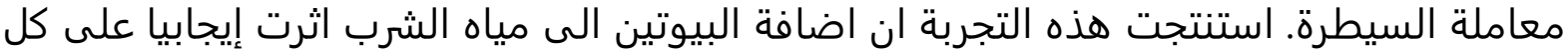
من الزيادة الوزنية و كفاءة التحويل الغذائي و كذلك معامل هضان هضم البرائل البروتين لدجاج فروج اللحم. 